\title{
First record of the Mozambique tilapia, Oreochromis mossambicus Peters, 1852 (Perciformes, Cichlidae), on Kangean Island, Indonesia
}

\author{
Veryl Hasan¹, Fajar Surya Pratama², Win Ariga Mansur Malonga ${ }^{3}$, \\ Annisa Bias Cahyanurani ${ }^{4}$
}

1 Universitas Airlangga, Faculty of Fisheries and Marine, Department of Fish Health Management and Aquaculture, Surabaya 60115, East Java, Indonesia

2 Ministry of Marine Affairs and Fisheries Republic of Indonesia, Directorat General of Marine and Fisheries Resources Surveillance, Tual Surveillance for Marine and Fisheries Resources Base, Tual 97651, Maluku, Indonesia

3 Universitas Teknologi Sumbawa, Faculty of Technobiology, Department of Bioctechnology, Sumbawa 84371, West Nusa Tenggara, Indonesia

4 Politeknik Kelautan dan Perikanan Sidoarjo, Department of Aquaculture Techniques, Sidoarjo 61253, East Java, Indonesia

Corresponding author: Veryl Hasan (veryl.hasan@fpk.unair.ac.id)

Academic editor: A.M. Leal-Zanchet | Received 20 April 2019 | Accepted 25 June 2019 | Published 22 July 2019

Citation: Hasan V, Pratama FS, Malonga WAM, Cahyanurani AB (2019) First record of the Mozambique tilapia, Oreochromis mossambicus Peters, 1852 (Perciformes, Cichlidae), on Kangean Island, Indonesia. Neotropical Biology and Conservation 14(2): 207-211. https://doi.org/10.3897/neotropical.14.e35601

\begin{abstract}
In 2019 we captured specimens of Oreochromis mossambicus Peters, 1852 from Batu Batu River, an estuary river on Kangean Island (Indonesia), a conservation area in the Java Sea. These records are among the first of this species from an island in the Java Sea. A description of morphological characters of sampled specimens is provided.
\end{abstract}

\section{Keywords}

Cichlid, distribution, estuary, non-native 


\section{Introduction}

Oreochromis mossambicus Peters, 1852 is a tilapia native to coastal regions and the lower reaches of rivers in southern Africa, from the Bushman River in the Eastern Cape to Zambezi River delta (Bruton and Boltt 1975; Cooper and Harrison 1992). It is now introduced to many countries for aquaculture (Arthington et al. 1984). Oreochromis mossambicus exhibits tolerance to salinity (de Moor et al. 1986; Russell et al. 2012). It can have negative impacts on aquatic communities through predation, competition for food and other resources, and as a vector of disease causing pathogens (Barker et al. 2002; Cucherousset and Olden 2011).

Tilapias have generally spread in mainland Indonesia (brackish and freshwaters) where aquaculture activities have been underway for some time (Basuki and Sri 2014). Kangean, one of islands in the Java Sea, is a conservation area and has no record of culturing tilapia. The presence of $O$. mossambicus on Kangean constitutes a new record.

Specimens of O. mossambicus were captured with land net on 18-19 March 2019. The specimens were preserved in $10 \%$ formalin solution and deposited at the Hydrobiology Laboratory, Brawijaya University, Malang, Indonesa (HB.Om.III.2019). Diagnostic morphological characters of the specimens were analyzed following Trewavas (1983).

New records. (Figs 1, 2). Indonesia: Java Sea: Kangean Island: Batu Batu River (655'09"S; $\left.115^{\circ} 19^{\prime} 53^{\prime \prime E}\right), 18-19$ March 2019, V. Hasan leg. (9 specimens, total length $6.6-23.1 \mathrm{~cm}$, photographed).

The meristic characters are shared with Orechromis mortimeri, and both species are close to Oreochromis spilurus in numbers of vertebrae, dorsal rays and gill rakers. Oreochromis placidus usually has five anal spines and a higher number of dorsal spines. Oreochromis urolepis has greater numbers of gill rakers and the mean number of dorsal rays is greater. Its pharyngeal teeth are somewhat coarser and adults may have a densely scaled caudal fin. Other specific morphological characters are as follows: Snout long; forehead with relatively large scales, starting with two scales between the eyes followed by nine scales up to the dorsal fin. Snout duckbill-like due to enlarged jaws, often causing upper profile to become concave. Pharyngeal teeth very fine and dentigerous area with narrow lobes, blade in adults longer than dentigerous area; lower gill rakers 14-20; caudal fin not densely scaled; vertebrae 28-31; dorsal spines 15-18; dorsal soft rays 10-13; anal spines 3; anal soft rays 7-12. All of these characters were found in the specimens of Tilapia from Batu Batu River, Kangean Island.

In the $20^{\text {th }}$ century alone, tilapias were introduced into many countries (Shelton and Popma 2006). Tilapias in general are listed among the top 100 worst alien species around the globe and have successfully established in more than 90 countries on five continents (all except Antarctica) (Russell et al. 2012).

The first establishment of tilapias is believed to have occurred in Java in the 1930 s as a result of an aquarium release of O. mossambicus (Courtenay and Wil- 


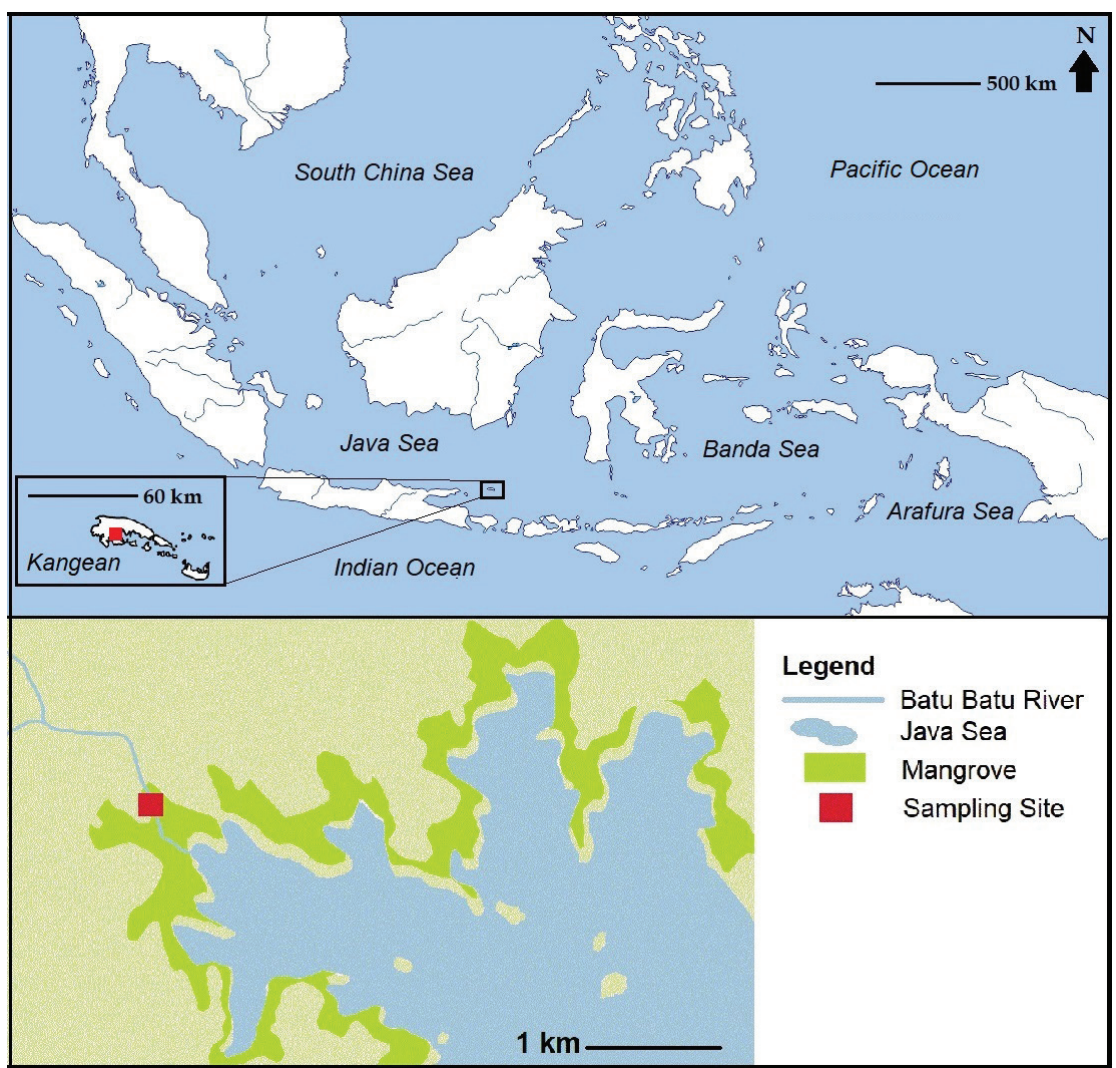

Figure 1. Location of Batu Batu River on Kangean Island (Indonesia) in the Java Sea.

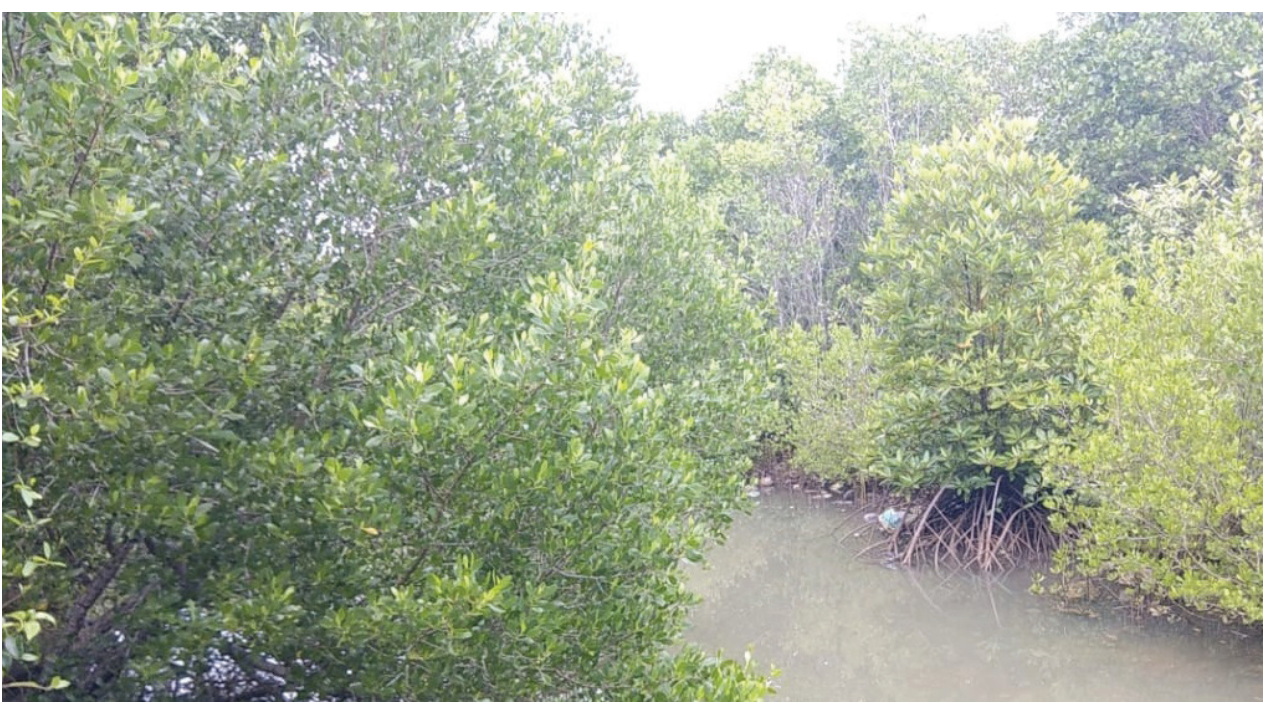

Figure 2. Batu Batu River, location where Oreochromis mossambicus was found on Kangean Island (Indonesia) in the Java Sea. 


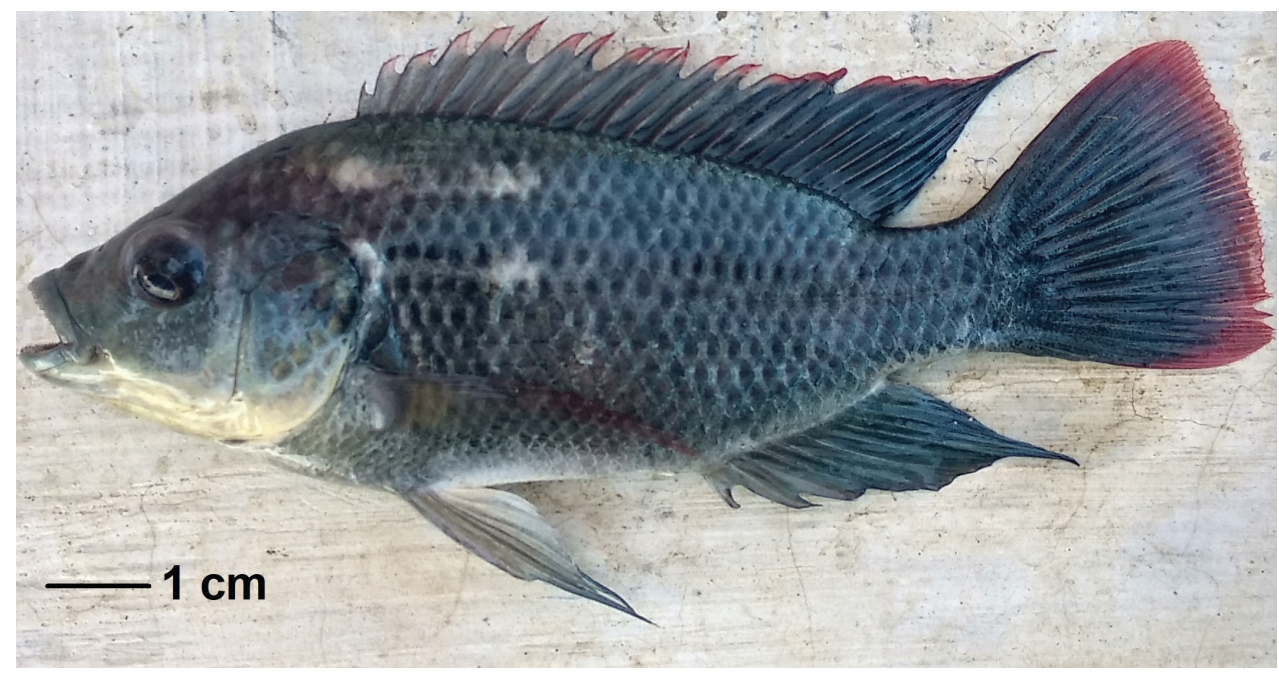

Figure 3. Fixed specimen of Oreochromis mossambicus (Hb.Om.III.2019) found in Kangean Island (Indonesia) in the Java Sea.

liams 1992). Due to aquaculture, O. mossambicus now occurs in all brackish and freshwaters of mainland Indonesia. Its presence on the estuary of Kangean Island, in the Java Sea and $185 \mathrm{~km}$ from the nearest maindland (Fig. 3), represents a new record. Estuary conditions on Kangean Island, namely temperature $27-30^{\circ} \mathrm{C}$; salinity 9-25 ppt, depth $0.5-2 \mathrm{~m}$ and current velocity $10 \mathrm{~cm} / \mathrm{s}$, are ideal for $O$. mossambicus reproduction and survival (Riede 2004).

We speculate that $O$. mossambicus was released into an estuary on the Kangean Island by local people, but the purpose is not clear. As the island does not have an aquaculture industry, further investigation is warranted to determine the source of O. mossambicus on Kangean Island. In the future further introductions should be prevented to reduce the impact of $O$. mossambicus on the conservation area on does not disturb the conservation area (de Silva et al. 2004; Picker and Griffiths 2011).

\section{Acknowledgements}

We thank the reviewers and editor for their insightful comments, a local fisherman as our guide, and the Ministry of Finance of the Indonesian as the Scholarship Program sponsor and for funding our research (no. 20160221035555).

\section{References}

Arthington AH, Mckay RJ, Russell DJ, Milton DA (1984) Occurrence of the introduced cichlid Oreochromis mossambicus (Peters) in Queensland. Australian Journal of Marine and Freshwater Research 35(2): 267-272. https://doi.org/10.1071/MF9840267 
Barker DE, Cone DK, Burt MDB (2002) Trichodina murmanica (Ciliophora) and Gyrodactylu spleuronecti (Monogenea) parasitizing hatchery-reared winter flounder, Pseudopleuronectes americanus (Walbaum): Effects on host growth an assessment of parasite interaction. Journal of Fish Diseases 25(2): 81-89. https://doi.org/10.1046/j.13652761.2002.00341.x

Basuki F, Sri R (2014) Analysis on the Survival Rate and Growth of Larasati Tilapia (Oreochromis niloticus) F5 seed in Saline Media. Procedia Environmental Sciences 23: 142147. https://doi.org/10.1016/j.proenv.2015.01.022

Bruton MN, Boltt RE (1975) Aspects of the biology of Tilapia mossambica Peters (Pisces: Cichlidae) in a natural freshwater lake (Lake Sibaya, South Africa). Journal of Fish Biology 7(4): 423-445. https://doi.org/10.1111/j.1095-8649.1975.tb04618.x

Cooper JAG, Harrison TD (1992) Effects of nesting activities of Oreochromis mossambicus (Pisces: Cichlidae) on bank stability in small lagoons. South African Journal of Science 88: 398-401.

Courtenay WR, Williams JD (1992) Dispersal of exotic species from aquaculture sources, with emphasis on freshwater fishes. In: Rosenfield A, Mann R (Eds) Dispersal of Living Organisms into Aquatic Ecosystems. University of Maryland Sea Grant Program, College Park, 49-81.

Cucherousset J, Olden JD (2011) Ecological impacts of non-native freshwater fishes. Fisheries (Bethesda, Md.) 36(5): 215-230. https://doi.org/10.1080/03632415.2011.574578

De Moor FC, Wilkinson RC, Herbst HM (1986) Food and feeding habits of Oreochromis mossambicus (Peters) in hypertrophic Hartbeesport Dam. South Africa. South African Journal of Zoology 21: 170-176. https://doi.org/10.1080/02541858.1986.11447976

De Silva S, Subasinghe R, Bartley D, Lowther A (2004) Tilapias as alien aquatics in Asia and the Pacific. A Review. FAO Fisheries Technical Paper, Rome, 453 pp.

Picker MD, Griffiths CL (2011) Alien and Invasive Animals - A South African Perspective. Randomhouse/Struik, Cape Town, 240 pp.

Riede K (2004) Global Register of Migratory Species-from Global to Regional Scales. Final Report of the R\&D-Projekt 80805 081. Federal Agency for Nature Conservation, Bonn, 329 pp.

Russell DJ, Thuesen PA, Thomson FE (2012) A review of the biology, ecology, distribution and control of Mozambique tilapia, Oreochromis mossambicus (Peters, 1852) (Pisces: Cichlidae) with particular emphasis on invasive Australian populations. Reviews in Fish Biology and Fisheries 22(3): 533-554. https://doi.org/10.1007/s11160-011-9249-z

Shelton WL, Popma TJ (2006) Biology. In: Lim CE, Webster CD (Eds) Tilapia: Biology, Culture, and Nutrition. Haworth Press, New York, 1-49.

Trewavas E (1983) Tilapiine fishes of the genera Sarotherodon, Oreochromis and Danakilia. British Museum (Natural History), London, 583 pp. 